\title{
An unusual occurrence of Pedinopariops (Trilobita: Phacopidae) within siliciclastic facies in the Devonian of Awaynat Wanin, Libya
}

\author{
Ryan C. McKellar, BRIAN D.E. Chatterton, Guido Meinhold \& Milad M. Ben Rahuma
}

\begin{abstract}
A new phacopid trilobite is described from the Givetian sequence of the Awaynat Wanin Group in the southern Ghadamis Basin, Libya. The specimen displays most of the eye and sculpture features necessary for a determination and can be restricted to Pedinopariops (Hypsipariops) Struve, 1982. The new specimen does not belong to any taxon known so far and hence is considered to be a new species. The specimen remains in open nomenclature and is assigned to Pedinopariops (Hypsipariops) sp. nov. A. This is the first Devonian trilobite described from Libya, and represents an unusual occurrence of Phacopidae in a relatively coarse siliciclastic facies. $\bullet$ Key words: Trilobita, Phacopidae, Devonian, Givetian, Awaynat Wanin, Ghadamis Basin, Libya.
\end{abstract}

\begin{abstract}
MCKellar, R.C., ChatTeRTON, B.D.E., Meinhold, G. \& BEN RAHUMA, M.M. 2012. An unusual occurrence of Pedinopariops (Trilobita: Phacopidae) within siliciclastic facies in the Devonian of Awaynat Wanin, Libya. Bulletin of Geosciences 87(2), 219-225 (3 figures). Czech Geological Survey, Prague. ISSN 1214-1119. Manuscript received June 14, 2011; accepted in revised form October 7, 2011; published online November 18, 2011; issued March 30, 2012.

Ryan C. McKellar (corresponding author), Department of Earth and Atmospheric Sciences, University of Alberta, 1-26 Earth Sciences Building, Edmonton, Alberta, T6G 2E3 Canada; rcm1@ualberta.ca・Brian D.E. Chatterton, Department of Earth and Atmospheric Sciences, University of Alberta, 1-26 Earth Sciences Building, Edmonton, Alberta, T6G 2 E3 Canada; bchatter@ualberta.ca • Guido Meinhold, CASP, University of Cambridge, West Building, 181a Huntingdon Road, Cambridge CB3 ODH, United Kingdom; present address: Department of Sedimentology \& Environmental Geology, Geoscience Center, University of Göttingen, Goldschmidtstr. 3, 37077 Göttingen, Germany; guido.meinhold@geo.uni-goettingen.de•Milad M. Ben Rahuma, Libyan Petroleum Institute, Gergarish Road, P.O. Box 6431, Tripoli, Libya; benrahumamilad@live.co.uk
\end{abstract}

The Ghadamis Basin (Fig. 1A) covers about $350,000 \mathrm{~km}^{2}$, with portions in eastern Algeria, southern Tunisia and north-western Libya, and hosts major oil and gas fields, amongst other rocks, in Devonian sandstones (Echikh 1998). In Libya, the Devonian rocks are subdivided from old to young into the Tadrart Formation, Ouan Kasa Formation, Awaynat Wanin Group and Tahara Formation (Hecht et al. 1964, Mergl \& Massa 2000, Ben Rahuma et al. 2008). The present study focuses on the Awaynat Wanin Group, which has its type section in the area of Awaynat Wanin (also spelt "Aouinet Ouenine") in the southern Ghadamis Basin (Fig. 1A). Here, fossiliferous siliciclastic strata are well exposed along the scarp of the Al Hamadah al Hamra plateau, containing, amongst other marine fossils, a well-studied brachiopod fauna (Mergl \& Massa 2000). Furthermore, a rare trilobite fauna has been mentioned in text form (Mergl \& Massa 2000) but without formal description or illustration.

During a field trip of the International Geoscience Programme Project 499 ("Devonian land-sea interaction:
Evolution of ecosystems and climate") to the Awaynat Wanin area (Königshof et al. 2008) one of the authors (GM) found a phacopid trilobite. Because of its palaeontological importance this specimen initiated a detailed investigation which is the focus of this paper.

\section{Geological setting}

The Awaynat Wanin area is located at the north-western margin of the basement high of Al Gargaf (also spelt "Al Qargaf") in central Libya (Fig. 1A). Here, the Awaynat Wanin Group appears to be disconformable over the Ouan Kasa Formation and consists of an alternation of fairly thick silty clay/claystone beds followed by relatively thin, ochre-coloured, fine- to coarse-grained sandstones (Ben Rahuma et al. 2008). Wave ripples, low angle parallel lamination, and trough and hummocky cross-stratification are common features. The sediments of the Awaynat Wanin Group were deposited in a shallow marine deltaic 
environment within the storm wave base, with prodelta silty clay/claystone beds passing upward into distributary channel sandstones (Vos 1981, Ben Rahuma et al. 2008). Fluvial intervals are minor but present. The direction of sediment transport was generally towards the northwest and west (Vos 1981).

In its type area, the Awaynat Wanin Group is subdivided into four formations, Awaynat Wanin I to IV, and is unconformably overlain by sandstones of the late Famennian Tahara Formation (Mergl \& Massa 2000, Ben Rahuma et al. 2008). Lateral thickness variations within the Awaynat Wanin Group are very frequent within a few kilometres (Mergl \& Massa 2000).

Macrofossils known from the type area of the Awaynat Wanin Group are mainly brachiopods, gastropods, bivalves, pteropods, trace fossils (e.g., Tigillites sp., Spirophyton sp., Diplocraterion sp.), casts of plant fossils, and rarely trilobites (Hecht et al. 1964, Mergl \& Massa 2000, Ben Rahuma et al. 2008). Analysis of the brachiopod fauna suggests a Middle to Late Devonian (Eifelian to Famennian) age for the Awaynat Wanin Group in its type area (Mergl \& Massa 2000).

\section{Previous trilobite findings}

Two species of trilobites, Phacops granulatus (Münster, 1840) and Greenops sp., have so far been reported from the Awaynat Wanin Group (Mergl \& Massa 2000, Ben Rahuma et al. 2008), however, in text form only without illustration or formal description and no clear stratigraphic assignment (i.e., no indication of the fossil locality in the logged section). This fauna together with the large bivalve Myalinella, bryozoans and rugose corals indicates a deeper, calmer subtidal environment and a latest Givetian age (Mergl \& Massa 2000). Note that Myalinella is predominantly found in the Carboniferous to Middle Triassic, but the family Myalinidae is present in the Devonian if Myalina squamosa Sowerby, 1827 is considered to be a true myalinid (McRoberts \& Newell 2005). Unfortunately, no formal description of Myalinella reported from the Awaynat Wanin Group can be found in the literature, which makes it difficult to accurately evaluate its stratigraphic significance.

\section{Sample locality}

The trilobite specimen was found about $3 \mathrm{~km}$ south-west of the Awaynat Wanin water well in a small gorge cutting the scarp of the Al Hamadah al Hamra plateau (geographic coordinates: N 28 $25^{\prime} 20^{\prime \prime}$ E $12^{\circ} 46^{\prime} 17^{\prime \prime}$ ) (Fig. 1B). The stratigraphic position of the sample is indicated in Fig. 2. The trilobite specimen was found about $20 \mathrm{~m}$ above the base of the Awaynat Wanin II Formation, which comprises fine- to medium-grained tidal and shoreface sandstones, recording a transgressive system tract (Ben Rahuma et al. 2008). Shell fragments, probably deposited by storms, are present in siltstones and sandstones at the level where the trilobite specimen was found.

\section{Materials and methods}

Morphological terminology generally follows that of Chlupáč (1977), and Crônier et al. (2011): most terms are also illustrated in these works.

Abbreviations. - Anatomical directions: d.v. - dorsoventral, exsag. - exsaggital, sag. - saggital, and tr. - transverse; L1-L3 - cephalic lobes, S0-S3 - cephalic sulci; institutions: SMF - Senckenberg Museum, Frankfurt am Main, Germany.

\section{Systematic palaeontology}

\section{Genus Pedinopariops Struve, 1972 Subgenus Pedinopariops (Hypsipariops) Struve, 1982}

Type species. - Pedinopariops (Hypsipariops) lyncops Struve, 1982.

Remarks. - The subgenus Pedinopariops (Hypsipariops) was recently elevated to the genus rank by Basse (2006), but we prefer to treat the taxon as a subgenus until there is cladistic support for such an elevation. Overarching similarities make distinctions difficult within the tribe Geesopini, and Pedinopariops (Hypsipariops) has been variably recognized at the subgeneric rank (e.g., Struve 1995), sunken within Pedinopariops (e.g., Basse 1998, Basse \& Weddige 2004), or treated as its own distinct genus.

\section{Pedinopariops (Hypsipariops) sp. nov. A}

Figures $3 \mathrm{~A}-\mathrm{F}$

Material examined. - The trilobite cephalon (an external mould, SMF 92899a) and its latex peel (a cast, SMF 92899b).

Diagnosis. - Glabella with reduced convexity on dorsal surface, and without significant overhang of anterior border; glabellar sculpture of low, mid-sized pustules with relatively wide spacing and nearly hemispherical shapes on dorsal surface, with pustules becoming crowded and fine with slight transverse expansion on anterior surface of glabella, and with transverse sculpture predominantly in small patch adjacent to anterior border; eyes long (exsag.) and 


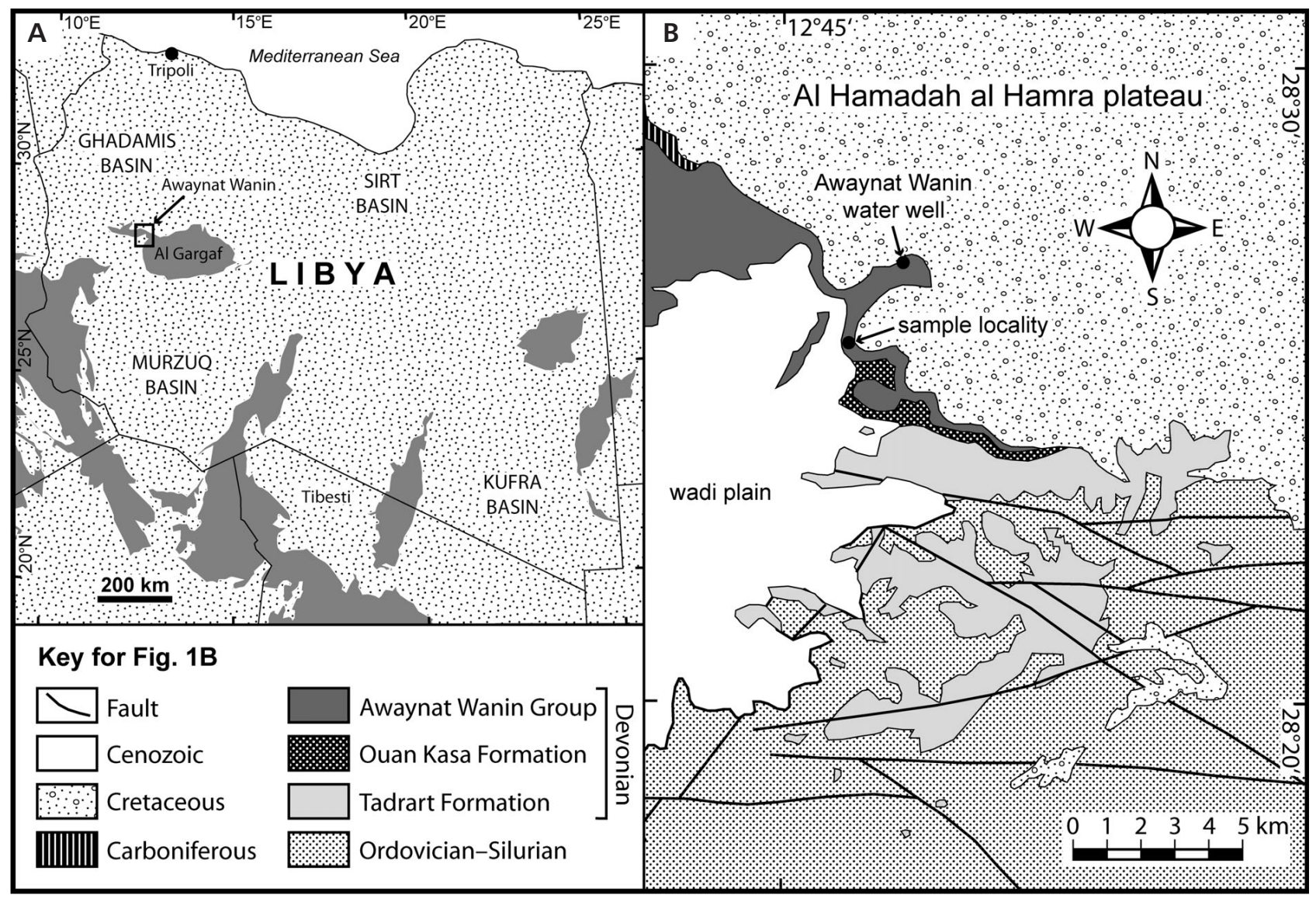

Figure 1. A - map of Libya showing surface outcrops with Palaeozoic rocks (dark grey colour) and the location of Awaynat Wanin in the southern Ghadamis Basin. • B - simplified geological map of the Awaynat Wanin area (after Gundobin 1985) showing the locality where the phacopid trilobite specimen was found.

low (close to lateral border) with 18 vertical rows of lenses and apparent maximum of 7 lenses per row; interlensar sclera thick with six tubercles surrounding each lens in hexagonal pattern; anterior margin of visual surface sloping; subocular distance very close to two-thirds of visual surface's dorsoventral height; L1 medial lobe (intercalating ring) positioned anterior to L1 lateral lobes and moderately large, with surface dorsally-recessed but bearing prominent central pad with either single large or multiple coalesced pustules; L1 lateral lobes small and recessed (dorsally) with low convexity and no apparent sculpture; palpebral furrow continuous and distinct; postocular and subocular pads effaced; cephalon marginulate; genal angle broadly rounded, not projecting posteriorly.

Description. - With exception of right gena and visual surface, most of cephalon preserved with no significant taphonomic distortion - extrapolation indicates cephalon with semicircular dorsal outline; proportionally, cephalon dominated by broad (tr.), short (exsag.) glabella, and large eyes spanning 0.58 of total cephalic length. Glabella subpentagonal in dorsal view and broadly domed (sag. and tr.), width approximately 0.53 of total cephalic width, with dorsal projection above eye approximately 0.28 times height of visual surface; fine pits sparse between glabellar pustules and also on genae, but difficult to observe due to preservation; axial furrows diverging anteriorly at approximately $60^{\circ}$, deeply-incised, broad, and slightly bowed (convex laterally), with furrow widening adjacent to palpebral lobe then narrowing and shallowing along anterior edge of eye and apparently terminating at deep subocular depression; L2 and L3 match convexity and sculpture of frontal lobe; L2 subrectangular in dorsal view, slightly narrower than medial lobe of L1 (exsag.); S2 and S3 relatively straight and well-impressed medially, but terminating far from axial furrow, with sulci trending near $21^{\circ}$ and $8^{\circ}$ behind transverse plane, respectively; anterior ramus of $\mathrm{S} 3$ effaced, widely separated from posterior ramus; S1, S0 and lateral furrows of L1 medial lobe all broad and shallow. Occipital ring long (exsag.) with steeply sloped anterior surface and weakly defined lateral lobes, and apparently with sculpture of low pustules constrained to posterior margin. Fixigena with palpebral area highly convex but positioned ventral to palpebral lobe (hidden in lateral 


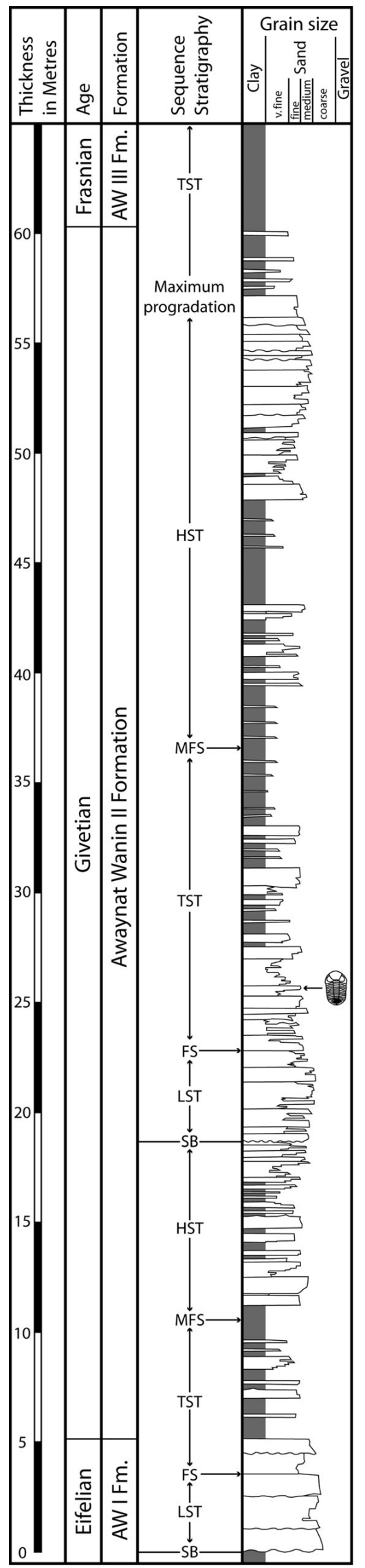

view), with four or five subdued pustules on dorsalmost surface, close to palpebral furrow; palpebral furrow broad and shallow in anterior reaches, but much narrower and deeper adjacent to posterior corner of eye; palpebral lobe relatively flat, with few reduced pustules along dorsalmost surface, and with weak palpebral rim; postocular area dominated by broad (exsag.) and deep posterior border furrow nearly square in section; postocular pad mainly visible due to curvature of lateral border furrow around ventral margin of pad; subocular area deeply incised and very narrow (d.v.), more so beneath anterior margin of eye, with faint outline of subocular pad only present adjacent to postocular pad; lateral surface of gena highly sloped; posterior border raised, with steeply inclined anterior margin, lateral border also raised, with contours almost matching those of visual surface in dorsal view; faint pustules or low tubercles sparse on both posterior and lateral borders, apparently becoming more pronounced and dense toward posterior margin, with no spines visible along posterior edge of gena, perhaps due to limited exposure. Eye with more than 91 lenses visible on single surface available (Fig. 3A, likely possessing about 99 lenses); interlensar sclera prominent, protruding approximately as far as lenses, and creating hexagonal lens packing with lenses separated from nearest neighbour by one-third of lens' diameter and six small tubercles surrounding each lens; margins of visual surface narrow and gently inflated, with ventral margin finely pitted with no other sculpture.

Discussion. - The new species is attributable to Pedinopariops (Hypsipariops) following either a traditional taxonomic approach (Struve 1972, 1995; Basse 2006) or a cladistic framework (McKellar \& Chatterton 2009). The only potential point of confusion stems from the position of the eye on the cephalon. Because the eye is short (d.v.) the subocular distance is almost exactly two-thirds of the height of the visual surface. This value straddles the diagnostic characters proposed by Struve (1995) for delimiting P. (Hypsipariops) (subocular distance $\geq$ two-thirds) and $P$. (Pedinopariops) (subocular distance $\leq$ two-thirds). As there are only two diagnostic criteria separating these subgenera, the identification hinges on a subjective assessment of the sculpture on the anterior surface of the glabella. This sculpture exhibits slight transverse elongation within a small area close to the anterior border in the new species, which is a $P$. (Hypsipariops) characteristic.

Figure 2. Simplified section of the Awaynat Wanin II Formation (modified from M.M. Ben Rahuma, unpublished data) showing locality where the phacopid trilobite specimen was found. Formation names and ages after Belhaj (1996) and Mergl \& Massa (2000). Abbreviations: SB - sequence boundary, LST - lowstand system tract, FS - flooding surface, TST - transgressive system tract, MFS - maximum flooding surface, HST - highstand system tract. 

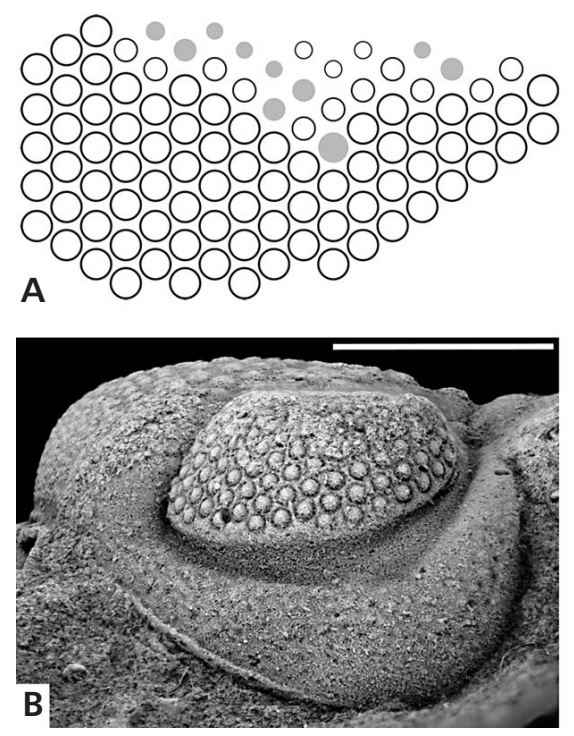
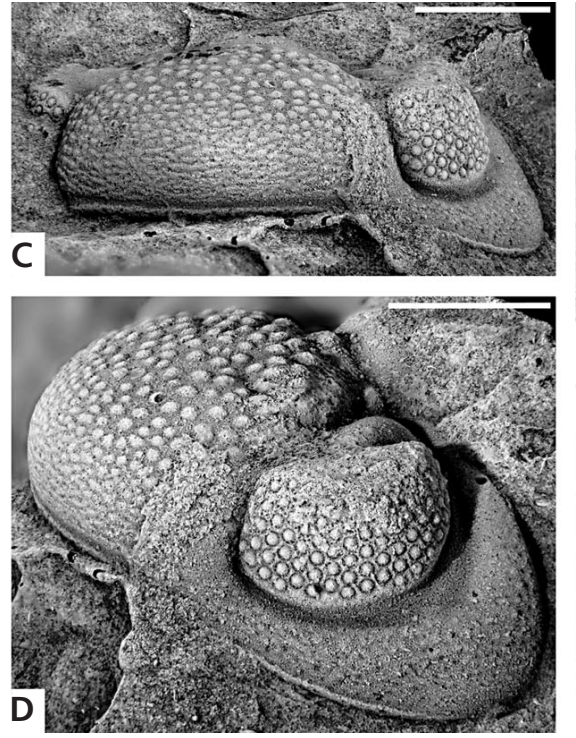
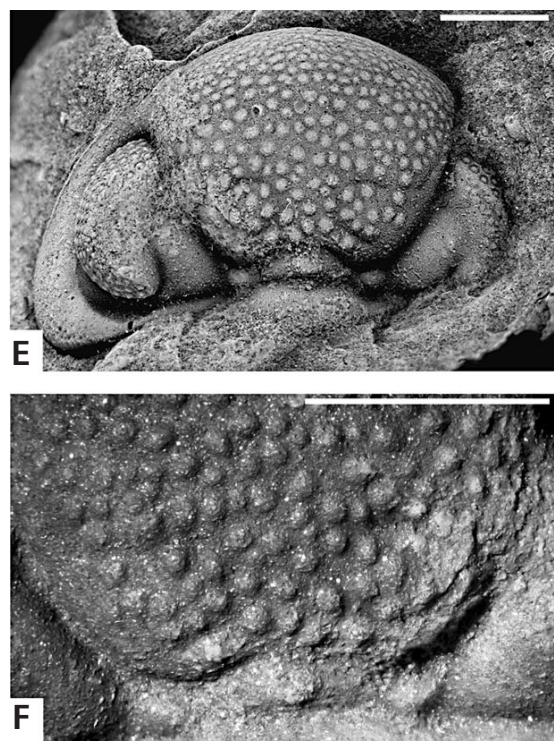

Figure 3. Pedinopariops (Hypsipariops) sp. nov. A. The cephalon is approximately $23.9 \mathrm{~mm}$ wide (tr.), if fully reconstructed. $\bullet$ A - eye diagram of lenses on left visual surface, with matrix-covered lenses or those inferred based on spacing indicated in grey. • B - lateral view of SMF $92899 \mathrm{~b}$ (latex peel, cast). $\bullet$ C - anterior view of SMF 92899b. $\bullet$ D - lateral-oblique view of SMF 92899b. $\bullet$ E - dorsal view of SMF $92899 b$. $\bullet$ F - detail of sculpture on posterior of glabella and L1 (bottom of image) for SMF 92899a (external mould). Scale bars = $5 \mathrm{~mm}$.

Within P. (Hypsipariops), the new species is most similar to P. (Hypsipariops) kowalskii (Struve 1992). The latter taxon differs in the presence of coarser and more prominent cephalic sculpture, a more pointed and posteriorly-projecting genal angle, a more vertical anterior margin to the eye, and a deeply incised axial furrow anterior to the eye. Pedinopariops (Hypsipariops) sp. nov. A possesses a visual surface that is somewhat ovoid in lateral view, which is largely an effect of the visual surface's strong adaxial inclination within its dorsal part. This eye shape and the gently rounded genal angle observed here appear to be unique within large holaspides of $P$. (Hypsipariops).

\section{Discussion and conclusions}

In all previous reports, Pedinopariops specimens have been encountered in predominantly carbonate facies, and range from the Emsian to the Givetian. Members of Pedinopariops have been reported by Struve (1995) as occurring within Lower Emsian to Lower Givetian strata from Europe and North Africa. In the revision of Basse (2006), $P$. (Hypsipariops) was listed as occurring within the upper Eifelian of Belgium; the upper Eifelian to middle Givetian of the Eifel Region, Germany; and the lower Givetian of Poland. In the same work, P. (Pedinopariops) was listed from the Eifelian of Belgium and northern France; the Eifelian, lower Givetian, and possibly the uppermost Emsian of the Eifel Region, Germany; and the Eifelian of western Germany. Subsequent finds have included $P$. (Pedinopariops) specimens from the lower Eifelian of northeastern
France (Crônier \& van Viersen 2008), and additional specimens of $P$. (Hypsipariops) from the lower Givetian of southern Morocco (McKellar \& Chatterton 2009). Based upon the known range of Pedinopariops (Hypsipariops) and current age constraints on the formation, we suggest that the lower portion of the Awaynat Wanin II Formation is early or middle Givetian in age at the studied section. The Spinocyrtia brachiopod assemblage described from the Awaynat Wanin II Formation by Mergl \& Massa (1992, 2000) has been viewed as an indicator of a latest Givetian age for the formation. However, the precise stratigraphic relationship between the described brachiopod assemblage and our trilobite specimen remains unknown, and the trilobite subgenus occurs predominantly within Eifelian and early Givetian strata elsewhere.

Although there are numerous specimens of Ordovician trilobites (e.g., Cocks \& Fortey 1988, BecqGiraudon \& Massa 1996) and a rich Ordovician to Devonian assemblage of arthropod trace fossils (e.g., Seilacher 1969, Seilacher et al. 2002) known from Libya, the specimen described here appears to be the first Devonian trilobite described from the region. Future studies on Libyan trilobites may give further support for the use of phacopid trilobites as biostratigraphic indicators for the correlation of Devonian strata within and between basins in North Africa (e.g., McKellar \& Chatterton 2008, 2009). In the interim, it is noteworthy that both the new species and Pedinopariops representatives from Morocco have been found in stratigraphic association with facies indicative of relatively shallow, high energy conditions and dominated by brachiopod remains. Unless the cephalon described 
here was transported into the depositional setting (which is unlikely due to its lack of mechanical damage, and against the prevailing direction of transport), the new species is a rare occurrence of Phacopidae in a siliciclastic facies.

Finding a phacopid cephalon within a relatively coarse siliciclastic unit may seem unremarkable, but it has large implications for the palaeohabitat of the family. Chlupác (1977) noted a conspicuous absence of phacopids in purely sandy units, suggesting that conditions in the associated depositional areas were not favourable to phacopids. Our specimen suggests that this ecological limitation may not have persisted throughout the Givetian, or that deltaic settings may have offered enough heterogeneity to support phacopids in a predominantly sandy setting. The connection between eye reduction in phacopids and variation in their palaeohabitat has been investigated very thoroughly (e.g., Crônier et al. 2004, Feist et al. 2009), but limited work has been done on the distribution of large-eyed phacopids like Pedinopariops, because the presence of large eyes is not exclusive to shallow water habitats. Chlupáč (1977) detailed a reduced diversity and abundance of phacopids from shallow water reefal assemblages and biostromes, and commented on the dominance of largeeyed phacopids in shallow water settings. Struve (1995) made similar remarks on the Pedinopariops and Drotops species he studied within North Africa, with the caveats mentioned above. Pedinopariops displays many of the characteristics that have been attributed to shallow water, predatory trilobites, including large eyes, thick cuticle, and a highly vaulted glabella (Fortey \& Owens 1999, Fortey \& Wilmot 1991). In Morocco, these traits are seen in conjunction with gigantism within phacopids such as Pedinopariops, and to an even greater extent within Drotops (Struve 1995, McKellar \& Chatterton 2009). In both Libya and Morocco, Pedinopariops has now been recovered from facies suggestive of shallow conditions. Hopefully, additional specimens will be obtained from siliciclastic units in Libya, clarifying the implications for phacopid palaeoecology.

\section{Acknowledgments}

The authors would like to thank Euan Clarkson and Catherine Crônier for comments that improved this paper. GM would like to thank the local specialists for the organization and guidance of the IGCP 499 workshop and the accompanying field trip in Libya. Logistical support by the Libyan Petroleum Institute is appreciated. RCM and BDEC would like to thank Stacey Gibb (University of Alberta, Canada) for assistance with creating the latex peels for this study, and Rudy Lerosey-Aubril (SMF) for assistance with collections. Funding was provided by NSERC and Alberta Ingenuity Fund support (to RCM), an NSERC Discovery Grant (to BDEC), and by CASP (to GM).

\section{References}

Basse, M. 1998. Trilobiten aus mittelerem Devon des Rhenohercynikums III. Proetida (3), Phacopida (2), Lichida (Lichoidea, Odontopleuroidea) und ergänzende Daten. Palaeontographica, Abteilung A 249, 1-162.

Basse, M. 2006. Eifel-Trilobiten IV: Proetida (3), Phacopida (3). 305 pp. Edition Goldschneck, Quelle \& Meyer Verlag, Wiebelsheim.

Basse, M. \& Weddige, K. 2004. Typen-Katalog der TrilobitenSammlung des Naturmuseums und Forschungsinstituts Senckenberg. Senckenbergiana lethaea 84, 141-172. DOI 10.1007/BF03043469

Becq-Giraudon, J.-F. \& Massa, D. 1996. Dreyfussina libyca nov. sp. (Trilobita, Phacopacea) de la Formation MelezChograne, Caradoc Supérieur de Libye. Geobios 20, 49-54. DOI 10.1016/S0016-6995(97)80008-3

Belhaj, F. 1996. Palaeozoic and Mesozoic Stratigraphy of Eastern Ghadamis and Western Sirt Basins, 57-96. In SALEM, M.J., Mouzughi, A.J. \& Hammuda, O.S. (eds) The Geology of Sirt Basin. Elsevier, Amsterdam.

Ben Rahuma, M., Proust, J.-N. \& Eschard, R. 2008. The Stratigraphic Evolution of the Devonian Sequences, Awaynat Wanin area, Southern Ghadamis Basin: a Fieldguide Book. 67 pp. Libyan Petroleum Institute, Tripoli.

Chlupéč, I. 1977. The phacopid trilobites of the Silurian and Devonian of Czechoslovakia. Rozpravy Ústředního ústavu geologického 43, 1-172.

Cocks, L.R.M. \& Fortey, R.A. 1988. Lower Palaeozoic facies and faunas around Gondwana, 183-200. In AudLEy-CHARLES, M.G. \& Hallam, A. (eds) Gondwana and Tethys. Geological Society Special Publications 37.

Crônier, C., Bignon, A. \& François, A. 2011. Morphological and ontogenetic criteria for defining a trilobite species: the example of Siluro-Devonian Phacopidae. Comptes Rendus Palevol 10, 143-153. DOI 10.1016/j.crpv.2010.10.003

Crônier, C., Feist, R. \& AufrRay, J.C. 2004. Variation in the eye of Acuticryphops (Phacopina, Trilobita) and its evolutionary significance: a biometric and morphometric approach. Paleobiology 30, 471-481.

DOI 10.1666/0094-8373(2004)030<0471:VITEOA>2.0.CO;2

Crônier, C. \& van Viersen, A. 2008. The 'Mur des douaniers', and exceptionally well-preserved Early Eifelian fossil site. Bulletin de la Société géologique de France 179, 89-95. DOI 10.2113/gssgfbull.179.1.89

EсHIKH, K. 1998. Geology and hydrocarbon occurrences in the Ghadames Basin, Algeria, Tunisia, Libya, 109-129. In MacGregor, D.S., Moody, R.T.J. \& Clark-Lowes, D.D. (eds) Petroleum Geology of North Africa. Geological Society Special Publication 132.

Feist, R., McNamara, K.J., Crônier, C. \& Lerosey-Aubril, R. 2009. Patterns of extinction and recovery of phacopid trilobites during the Frasnian-Fammenian (Late Devonian) mass extinction event, Canning Basin, Western Australia. Geological Magazine 146(1), 12-33.

DOI $10.1017 /$ S0016756808005335

Fortey, R.A. \& OwENS, R.M. 1999. Feeding habits in trilobites. Palaeontology 42(3), 429-465.

DOI 10.1111/1475-4983.00080 
Fortey, R.A. \& Wilmot, N.V. 1991. Trilobite cuticle thickness in relation to palaeoenvironment. Paläontologische Zeitschrift 65(1/2), 141-151.

Gundobin, V.M. 1985. Geological map of Libya 1:250,000: Qararat Al Marar NH 33-13. Industrial Research Centre, Tripoli.

Hecht, F., Fürst, M. \& KLitzsch, E. 1964. Zur Geologie von Libyen. Geologische Rundschau 53, 413-470.

Königshof, P., Ben Rahuma, M. \& Proust, J.-N. 2008. IGCP 499: Devonian land-sea transitional settings. Episodes 31, 438-439.

McKellar, R.C. \& Chatterton, B.D.E. 2008. Biostratigraphy and systematics of select Lower and Middle Devonian Phacopidae (Trilobita) from Southern Morocco, 259-264. In Rábano, I., Gozalo, R. \& García-Bellido, D. (eds) Advances in trilobite research. Del Museo Geominero, Instituto Geológico y Minero de España, Madrid 9.

McKellar, R.C. \& Chatterton, B.D.E. 2009. Early and Middle Devonian Phacopidae (Trilobita) of southern Morocco. Palaeontographica Canadiana 28, 1-110.

McRoberts, C.A. \& Newell, N.D. 2005. Marine Myalinidae (Bivalvia: Pterioida) from the Permian of West Texas. American Museum Novitates 3469, 1-15. DOI 10.1206/0003-0082(2005)469<0001:MMBPFT>2.0.CO;2

Mergl, M. \& Massa, D. 1992. Devonian and Lower Devonian brachiopods and bivalves from Western Libya. Biostratigraphie du Paleozoique 12, 1-115.

Mergl, M. \& MAssa, D. 2000. A palaeontological review of the Devonian and Carboniferous succession of the Murzuq Basin and the Djado Sub-Basin, 41-88. In Sola, M.A. \& Worsley, D. (eds) Geological Exploration in Murzuq Basin. Elsevier, Amsterdam.

MüNSTER, G.G. 1840. Die Versteinerungen des Uebergangskalkes mit Clymenien und Orthoceratiten von Oberfranken. Beiträge zur Petrefacten-Kunde 3, 33-121.

SeILACHER, A. 1969. Sedimentary rhythms and trace fossils in Paleozoic sandstone of Libya, 117-123. In KANNES, W.H. (ed.) Geology, archeology and prehistory of southwestern Fezzan, Libya. $11^{\text {th }}$ Annual Conference. Tripoli.

Seilacher, A., LÜNing, S., Martin, M.A., Klitzsch, E., Khoja, A. \& CRAig, J. 2002. Ichnostratigraphic correlation of Lower Palaeozoic clastics in the Kufra Basin (SE Libya). Lethaia 35, 257-262. DOI 10.1080/00241160260288848

Struve, W. 1972. Phacops-Arten aus dem Rheinischen Devon. 2. Untergattungs-Zuweisung. Senckenbergiana lethaea 53, 383-403.

Struve, W. 1982. Beiträge zur Kenntnis der Phacopina (Trilobita), 10: Neue Untersuchungen über Geesops (Phacopinae; Unter- und Mittel-Devon. Senckenbergiana lethaea 63, 473-495.

Struve, W. 1992. Neues zur Stratigraphie und Fauna des rhenotypen Mittel-Devon. Senckenbergiana lethaea 71, 503-624.

Struve, W. 1995. Die Riesen-Phacopiden aus dem Maïder, SE-marokkanische Prä-Sahara. Senckenbergiana lethaea 75, 77-129.

Vos, R.G. 1981. Deltaic sedimentation in the Devonian of western Libya. Sedimentary Geology 29, 67-88. 